\title{
Pluralisme Hukum Dalam Bingkai Masyarakat Madani: Masa Nabi dan Masa Kini
}

\author{
Muhammadun \\ Institut Agama Islam Bunga Bangsa Cirebon \\ Murjazin \\ UIN Sunan Kalijaga Yogyakarta
}

\begin{abstract}
Abstrak
Di era modernisasi, hukum tidak lagi dipahami sebagai sistem norma yang mengikat setiap warga negara. Dalam praktiknya, hukum dikendalikan dan diawasi oleh negara melalui sejumlah regulasi yang dibuat dan disusun oleh komunitas tertentu yang memiliki akses langsung ke negara. Tulisan ini akan mengupas lebih jauh tentang konsep pluralisme hukum yang pernah diterapkan dalam sejarah sosial hukum Islam, serta mendeskripsikan kasus-kasus pluralisme hukum yang dipraktikkan pada masa Nabi dan juga sahabat.
\end{abstract}

\begin{abstract}
In the era of modernization, law is no longer understood as a norm system that binds every citizen. In practice, the law is controlled and supervised by the state through a number of regulations created and compiled by certain communities that have direct access to the state. This paper will explore more about the concept of legal pluralism that once applied in the social history of Islamic law, as well as describing cases of legal pluralism that were practiced during the time of the Prophet and also friends.
\end{abstract}

Keywords: Legal Pluralism, Civil Society, the Present and Prophet's Period.

\section{Pendahuluan}

Pluralisme hukum muncul berawal dari sebuah realitas masyarakat majemuk saling berinteraksi satu sama lain sesuai dengan identitas yang dimiliki. Setiap masyarakat bukanlah lahir dari sistem nilai tunggal (monovalue), melainkanterdapat beragam sesuatu dalam bentuk budaya, adat, suku maupun ras. Keragaman ini bukanlah sesuatu yang harus dinafikan, dihindari atau dipaksakan dalam satu "wadah" hukum yang dikenal dengan hukum sentralistik (legal centralism). Sebaliknya, keragaman sistem nilai dapat dikelola dengan baik melalui cara pandang keragaman nilai, tanpa melupakan nilai-nilai tertentu sebagai bagian identitas masyarakat.

Di era modernisasi, hukum tidak lagi dipahami sebagai sebuah sistem norma yang mengikat setiap warga negara. Dalam pelaksanaannya, hukum dikontrol dan diawasi oleh negara melalui sejumlah regulasi yang dibuat dan disusun oleh komunitas tertentu yang memilki akses langsung dengan negara. Konsekuensinya berdampak pada munculnya pada sifat sentralistik hukum, dalam hal tertentu sering terabaikan sistem nilai yang berkembang dalam masyarakat majemuk. Sistem nilai yang terdapat pada setiap masyarakat menjadi pengikat sosial dan menggerakkan kehidupan ekonomi, sosial masyarakat melalui prinsip 
timbal balik (principle of reciprocity) dan prinsip publisitas (principle of publisitas) yang telah berlangsung secara bersama-sama. ${ }^{1}$

Keragaman dan kemajemukan sistem nilai menuntut pemberlakuan hukum tidak hanya berkutat pada sistem sentralistik sebagai akibat dominasi penguasa. Tidak heran pada masa sekarang, atas dasar teologi kepastian hukum dalam sistem sentralistik menggiring pada upaya memudarkan sistem nilai yang menjadi perekat atau pengendalian sosial masyarakat majemuk. ${ }^{2}$

Dalam khazanah keislaman, pluralisme hukum bukanlah sesuatu hal baru, melainkan ajaran yang terkandung dalam konsep rahmatan lil 'alamin. Konsep ini didukung oleh sejumlah ayat suci al-Qur'an dan praktek Nabi ketika diberi kepercayaan memimpin komunitas lintas primordial; suku, ras, dan agama. Catatan sejarah membuktikan keberagaman budaya, suku, kasta sosial masyarakat Arab mendapat pengakuan dalam tradisi keislaman. Meskipun masih terdapat perbedaan cara pandang dari suku-suku atau kabilah-kabilah Arab, namun perbedaan tersebut dapat disatukan dalam sebuah perjanjian bersama antar suku.

Perjanjian lintas primordial dituangkan dalam sebuah dokumen resmi yang dikenal dengan sebutan Piagam Madinah. Dokumen ini sebagai bukti diakuinya paham pluralisme hukum guna mengakomodir hukum-hukum yang masih hidup dan masih dianut oleh komunitas suku-suku masyarakat Arab. Demikian pula di kalangan internal muslim Anshor dan muslim Muhajirin senantiasa mengesampingkan paham primordialisme sebagai cikal bakal lahirnya masyarakat Madinah. Padahal sebelumnya kaum Muhajirin dan Anshor berasal dari beragam suku atau kabilah yang sering terjadi pertikaian dan selalu menampakkan sikap "ego" sektoral, primordial, teritorial kesukuan, kehormatan suku dengan mengandalkan kekuatan fisik.

Realitas sejarah menunjukkan masyarakat Madinah adalah masyarakat plural, yang dipimpin oleh Nabi Muhammad SAW. sebagai penguasa sekaligus pemimpin warga negara Madinah memberi kebebasan kepada warganya melaksanakan sistem nilai yang telah berjalan dan melekat pada setiap warga negara. Keberhasilan Nabi menyatukan sejumlah kepentingan suku-suku Arab, tanpa memarjinalisasikan kepentingan kelompok atau suku tertentu saja, serta melahirkan masyarakat berperadaban atau masyarakat ideal menjadi inspirasi pemikir Barat menggagas kembali masyarakat modern, yang dikenal dengan istilah civil society. ${ }^{3}$ Konsep ini selanjutnya berkembang di abad modern yang dikemas dalam bentuk pluralisme, demokrasi, reformasi, dan penguatan masyarakat sipil. ${ }^{4}$

${ }^{1}$ Hubungan resiprositas (reciprocity) dan publisitas (publicity) merupakan kriteria yang membantu menjelaskan hak dan kewajiban masyarakat untuk menjaga keteraturan sosial. Hubungan keduanya banyak digunakan dalam kebebasan (custom) masyarakat. I Nyoman Nurjaya, Perkembangan Pemikiran Konsep Pluralisme Hukum, dalam http://www.huma.co.id. (1-17). 117.

${ }^{2}$ Sunyoto Usman, Esai-Esai Sosiologi Perubahan Sosial, (Yogyakarta: Pustaka Pelajar, 2015), 116-

${ }^{3}$ Munculnya ide civil society adalah upaya membangkitkankembali kesadaran masyarakat terhadap hak-hak sipil (rakyat) sebagai akibat dari penindasan sewenang-wenang terhadap rakyat oleh kelompok oportunis atau penguasa. Civil society awalnya muncul di negara Barat modern. Ia muncul bersamaan dengan proses modernisasi dalam rentang waktu terjadinya transformasi dari masyarakat feodal menuju masyarakat barat modern. Dalam tradisi Eropa (pertengahan abad XVIII), civil society dipahami sama dengan negara (state), yakni suatu kelompok atau kekuatan yang mendominasi seluruh kelompok masyarakat 
Makalah ini akan mengeksplorasi lebih lanjut tentang konsep pluralisme hukum yang pernah berlaku dalam sejarah sosial hukum Islam, sekaligus memaparkan kasuskasus pluralisme hukum yang dipraktekkan pada masa Nabi dan juga sahabat. Pengalaman sejarah dijadikan dasar dalam mengkaji dan membingkai konsep pluralisme sebagai salah satu instrumen pembentukan masyarakat madani. Pembahasan dimulai dengan memaparkan issu-issu di seputar konsep pluralisme hukum, kemudian dilanjutkan dengan menjelaskan konsep pluralisme hukum sebagai pantulan dalam memotret keberagaman sistem nilai masyarakat yang sedang berupaya berupaya menggagas kembali wacana masyarakat madani.

\section{Pluralisme Hukum: Sebuah Konsep Awal}

Werner Menski dalam bukunya Comparative Law in a Global Contex (The Legal System of Asia and Afrika) mendefinisikan pluralisme hukum (legal pluralism) yaitu pendekatan dalam memahami pertalian antara hukum negara (positive law), aspek kemasyarkatan (socio-legal approach) dan natural law (moral/ethic/religion). ${ }^{5}$ Dari definisi itu, pluralisme ${ }^{6}$ hukum dikonsepsikan sebagai cara pandang memahami hukumhukum yang hidup dalam masyarakat dapat berdampingan dengan hukum yang diberlakukan oleh negara. Unsur terpenting yang menjadi karakteristik dalam pluralisme hukum menurut definisi ini adalah bekerjanya semua sistem hukum secara utuh, bukan parsial. Unsur interaksi menjadi inheren dalam memahami konsep pluralisme karena erat kaitannya dengan sistem hukum yang hidup dalam masyarakat majemuk. Hukum yang hidup dalam masyarakat didasarkan oleh sebuah kenyataan sosial masyarakat yang

lain. Dalam perkembangan selanjutnya, istilah state dan civil society mengalami pergeseran makna. Civil society dipahami konteks interaksi-reltionship, antara rakyat dengan penguasa dan antara rakyat dengan rakyat. A. Ubaidillah, dkk., Pendidikan Kewarganegaraan: Demokrasi, HAM dan masyarakat Madani, (Jakarta: IAIN Jakarta Press, 2000), 137.

4 Terdapat beberapa istilah yang memiliki konotasi kesamaan makna dengan istilah masyarakat madani, yaitu civil society, masyarakat warga, masyarakat sipil, masyarakat beradab, atau masyarakat berbudaya. Secara kebahasaan semua istilah yang digunakan bertujuan untuk menggambarkan konsep masyarakat madani, meskipun terdapat perbedaan dalam memahami maksud dan tujuan istilah terkait masyarakat madani. Adi Suryadi Culla, Masyarakat Madani: Pemikiran, Teori dan Relevansinya dengan Cita-Cita Reformasi, (Jakarta: Raja Grafindo Persada, 1999), 3-9. Namun tulisan ini tidak mengetengahkan perbedaan konsep masyarakat madani dengan istilah-istilah terkait. Perbedaan cara pandang di atas berangkat dari asumsi berbeda, sehingga terdapat kesulitan untuk menetapkan kesamaan makna dan konsep. Untuk itulah dalam penjelasan selanjutnya istilah yang digunakan adalah masyarakat madani, yaitu sebuah konsep yang berusaha menggerakkan kembali kesadaran multikulturalisme (keragaman budaya) masyarakat sipil sebagai reaksi dari keberpihakan negara pada sistem monokulturalisme (penunggalan atau peyeragaman budaya) dengan menggunakan pendekatan asimilasionisme (minoritas membaur dalam mayoritas), dengan tujuan mengurangi dominasi kekuasaan negara. Azyumardi Azra, dkk., Mencari Akar Kultural Civil Society di Indonesia, (Ciputa Jakarta: INCIS, 2003), 85; Thoha Hamim, "Islam dan Masyarakat Madani", dalam Sudarno Shobron dan Mutohharun Jinan (ed.), Islam, Masyarakat Madani, dan Demokrasi, (Yogyakarta: Muhammadiyah University Press, 1999), 106-107.

${ }^{5}$ Werner Menski, Comparative Law in a Global Contex: The Legal System of Asia and Afrika, Cambridge University Press, 2006, 187.

${ }^{6}$ Beberapa istilah yang terkait dengan pluralisme adalah plural, pluralis, dan pluralitas. Plural berarti jamak atau lebih dari satu. Sedangkan pluralis adalah kategori jumlah yang menunjukkan lebih dari satu atau lebih dari dua dalam bahan yang mempunyai dualis. Pluralis ialah banyak macam; bersifat majemuk, di Indonesia pluralis menunjukkan kepada sebuah keadaan masyarakat yang majemuk. Sedangkan pluralisme menunjukkan kepada sebuah kelompok atau komunitas yang berhubungan dengan keadaan masyarakat majemuk berkaitan erat dengan sistem sosial dan politik. Tim Penyusun Kamus Pusat Bahasa, Kamus Besar Bahasa Indonesia, (Jakarta: Depdikbud, 1999), 54. 
memiliki keragaman sistem hukum, sebagai wujud dari identitas sosial-budaya masyarakat. Keragaman identitas masyarakat dapat ditemukan dalam bentuk hukum adat, hukum agama, dan hukum negara.

Pentingnya mengkonseptualisasi pluralisme hukum tidak dimaksudkan untuk membuat sistem hukum baru, melainkan sebuah paradigma berpikir menekankan pada aspek pengakuan atas keragaman hukum yang berlaku dalam masyarakat, dalam kondisi tertentu terkadang belum terakomodir dengan baik oleh sistem hukum negara yang bersifat sentralistik.

Secara akademik, pluralisme hukum adalah bagian dari kajian antropologi hukum. Hukum dalam kajian antropologi mengandung konsep normatif dan kognitif untuk menjelaskan keragaman hukum yang satu sama lainnya memiliki sistem (cluster) hukum berbeda. ${ }^{7}$ Atas dasar itulah hukum dipandang sebagai hasil interaksi sosial terkait oleh unsur-unsur kebudayaan dalam arti luas, meliputi politik, ekonomi, ideologi, agama, struktur sosial. Hukum dalam perspektif ini berbentuk peraturan-peraturan lokal yang bersumber dari suatu kebiasaan masyarakat (customary law/folk law), termasuk pola di dalamnya mekanisme-mekanisme pengaturan dalam masyarakat (self regulation) yang juga berfungsi sebagai sarana pengendalian sosial (legal order). ${ }^{8}$

Berbeda dengan cara pandang tentang hukum dalam perspektif hukum negara (state law), semata-mata mengedepankan hukum yang telah dipositifkan dalam sejumlah regulasi power (kekuasaan). Model cara pandang hukum ini adalah model berpikir positifistik yang dpengaruhi oleh filsafat ilmu-ilmu kealaman dalam menjelaskan realitas masyarakat. ${ }^{9}$ Tentunya cara pandang ilmu alam yang bersifat positifistik dalam menjelaskan realitas sosial kemasyarakatan menyebabkan terjadinya sakralisasi pemikiran hukum. Hukum dipandang dari satu aspek saja yang dapat dibuktikan melalui jalan pikir ilmu alam (positivistik). Padahal dalam kajian ilmu-ilmu sosial, hukum yang hidup dalam masyarakat selalu mengalami perubahan sejalan dengan perubahan masyarakat. Perubahan akan dipengaruhi oleh aspek budaya, bahasa, struktur sosial, dan agama. Kenyataan ini menggiring pada pamahaman bahwa kajian tentang pluralisme hukum tidak hanya didekati dengan satu disiplin ilmu saja, melainkan melibatkan multidisiplin ilmu agar hukum yang dipahami memiliki keragaman makna sejalan dengan keragaman identitas masyarakat.

Dalam perkembangannya terjadi pergeseran makna tentang makna pluralisme hukum seiring kehadiran dunia globalisasi. Sulistiyowaty Irianto memetakan

\footnotetext{
${ }^{7}$ Keebet Benda-Beckmann, The Context of Law, xii th internasional Congress of the Commission on Folk Law and Legal Pluralism,: Legal Pluralism and Unofficial Law in Social, Economic and Political Development, Chiang Mai, April, 2002; Sulistiyowati Irianto, "Pluralisme Hukum Sebagai Suatu Konsep dan Pendekatan Teoretis dalam Perspektif Global", disampaikan dalam seminar tentang "Pluralisme Hukum dan Tantangannya Bagi Pembentukan Sistem Hukum Nasional", kerjasama Badan Pembinaan Hukum Nasional DephumHam, FH Universitas Hasanuddin, dan Kantor Wilayah Dephuk HAM Sulawesi Selatan, Makasar, 1-2 Mei 2007; Faisal, Pluralisme Hukum di Indonesia: Kekuatan, Kelemahan, Peluang dan Ancaman, (Yogyakarta: Maghza, 2013), 125. Artikel ini juga ditelusuri dalam Asosiasi Studi Sosio Legal Indonesia, https://asslesi.wordpress.com.

8 I Nyoman Nurjaya, Perkembangan Pemikiran Konsep Pluralisme Hukum, dalam http://www.huma.co.id. 2-3. (1-17).

9 Soetandyo Wignjosoebroto, Pergeseran Paradigma dalam Kajian-Kajian Sosial dan Hukum, (Malang: Setara Press, 2013), 78-79.
} 
perkembangan pluralisme hukum kepada tiga periode. ${ }^{10}$ Periode awal, yaitu pertengahan abad ke-19 (1960-1970 an) dan abad ke-20. Abad ke-19 keragaman sistem hukum dipandang sebagai gejala evoolusi hukum, sedangkan abad ke-20, keragaman hukum dipahami sebagai gejala pluralisme hukum. Sekalipun terdapat perbedaan dalam memposisikan keragaman hukum pada periode awal, namun Sulistiyowaty menyimpulkan adanya kesamaan pandangan, yaitu pluralisme hukum doartikan upaya mempertahankan keberadaan sistem hukum (ko-eksistensi) dalam lapangan sosial tertentu yang dikaji. Hukum dikaji hanya terbatas pada usaha pemetaan terhadap keanekaragaman hukum dalam lapangan kajian tertentu (mapping of legal universe). ${ }^{11}$

Karakteristik pandangan keragaman sistem hukum periode ini terjadi dikotomi pemahaman tentang hukum; masing-masing sistem hukum menampilkan eksistensinya. Sulistiyowaty memberi contoh konsep pluralisme yang ditawarkan oleh Sally Engle Merry, pluralisme hukum adalah "is generally defined as a situation in which two or more legal systems coexist in the same social field”. (Merry, 1988:870).

Periode kedua (akhir 1990-an), konsep pluralisme hukum pada tahap ini dikaitkan dengan hubungan individu yang menjadi subyek dari pluralisme hukum. Setiap individu saling mempengaruhi satu sama lainnya dalam keragaman sistem hukum yang berlaku. Disini, hukum dipahami sebagai hasil interaksi yang saling mempengaruhi antara sistem hukum yang berlaku. Seperti hubungan hukum adat dan hukum agama, satu sama lainnya saling mempengaruhi. Menurut Sulistiyowati, munculnya pendekatan yang tidak tergantung pada pola mapping of the legal universe, merupakan kontribusi positif dalam rangka mencari pendekatan yang dapat menyederhanakan gejala hukum yang rumit dalam masyarakat. Pluralisme hukum juga terdapat dalam sistem hukum rakyat (folk law), seperti hukum agama, adat, dan kebiasaan-kebiasaan lain yang saling "bersaing”. Demikian pula denngan sistem hukum negara yang memiliki sifat plural. Dalam banyak situasi pluralisme dalam hukum negara dapat dijumpai adanya choice of law dan bahkan conflict of law. Demikian pula dengan adanya pembagian jurisdiksi normatif secara formal seperti pengaturan pada badan-badan korporasi, lembaga-lembaga politik, badan-badan ekonomi, dan badan-badan administrasi yang berada dalam satu sistem.

Periode ketiga adalah pluralisme hukum di era globalisasi, ciri pluralisme hukum dalam perspektif global memfokuskan saling ketergantungan, adopsi, atau saling pengaruh (interdependensi, interfaces) antara berbagai sistem hukum. Interdepedensi terjadi antara sistem hukum internasional, nasional, dan hukum lokal, kajian-kajian yang berkembang dalam antropologi hukum dimulai pada dampak kebijakan dan kesepakatan-kesepakatan internasional terhadap sistem hukum dan kebijakan di tingkat nasional berpengaruh pada sistem hukum dan kebijakan di tingkat daerah.

Paradigma baru dalam pluralisme hukum sangat erat kaitannya dengan fenomena globalisasi, hukum dari berbagai level bergerak memasuki wilayah-wilayah tanpa batas, dan terjadi persentuhan dan adopsi yang kuat di antara hukum internasional, transnasional,

\footnotetext{
${ }^{10}$ Sulistiyowati Irianto, Pluralisme Hukum Sebagai Suatu Konsep dan Pendekatan Teoretis dalam Perspektif Global, 2007.

${ }^{11}$ Sulistiyowati Irianto, Pluralisme Hukum Sebagai Suatu Konsep dan Pendekatan Teoretis dalam Perspektif Global, 2007.
} 
nasional dan lokal. Kondisi ini tidak tetap membuat pemetaan hukum tertentu (internasional, nasional, lokal), serta mempertegas batas-batas entitas terpisah dari sistem hukum lain.

\section{Pluralisme Hukum Pada Masa Nabi}

Secara doktrinal, pluralisme hukum mendapat pengakuan dalam al-Qur'an merupakan wujud nyata munculnya keragaman etnis, warna kulit dan suku bangsa. Berdasarkan catatan sejarah, konsep pluralisme hukum telah dipraktekkan Nabi sebagai penguasa masyarakat plural, masing-masing mereka melekat hukum-hukum yang berlaku dalam tradisi Arab Jahiliyah. Pluralisme hukum tidak hanya sebatas wacana akadmeik dipandang sebagai sesuatu yang baru di zaman modern. Paling tidak pendekatan dan sistem sosial masyarakat turut membedakan ajaran pluralisme hukum pada masa Nabi dengan konsep pluralisme hukum di abad modern.

Fakta sejarah membuktikan adanya sebuah dokumen resmi yang membuat ajaran pluralisme hukum dijadikan pegangan dan dasar oleh Nabi untuk menggambarkan bekerjanya sistem hukum yang hidup pada saat itu. Pada masa ini sistem hukum yang berlaku tidak terbatas pada hukum al-Qur'an (Islam), akan tetapi sistem hukum agama selain Islam, termasuk hukum adat keberadaannya diakui dan dijamin oleh Nabi sebagai kepala negara. Fakta ini menjadi pembeda konsep pluralisme hukum dalam konteks sekarang adanya sistem hukum sentralistik (negara) sebagai hukum dominan, sehingga sistem hukum yang hidup dalam masyarakat menjadi terabaikan. Akibatnya terjadi disharmonisasi sistem hukum dan menimbulkan kesan adanya pemaksaan hukum tunggal yaitu hukum negara.

Interaksi sistem hukum dalam masyarakat Madinah dituangkan dalam dokumen resmi yang dikenal dengan sebutan Piagam Madinah, ${ }^{12}$ yaitu sebuah hasil kesepakatan yang terdiri dari beragam suku, agama dan prestise sosial lainnya untuk membentuk satu komunitas ideal (ummah) ${ }^{13}$ Konsep ummah menggambarkan formulasi masyarakat ideal bertindak secara kolektif membangun ketertiban sosial dan ketentraman. Konsep inilah yang diinginkan dalam konteks abad modern yang menggunakan istilah masyarakat madani atau civil society.

Fondasi yang dibangun dalam masyarakat madani terbentuknya masyarakat religius yang mengakui keragaman sistem hukum dari berbagai suku. Harmonisasi sistem hukum terlihat dalam kasus tindak pidana zina yang dilakukan oleh seorang Yahudi, Nabi memberikan hukuman kepada pelaku zina bukan berdasarkan hukuman yang terdapat dalam ajaran Islam. Akan tetapi Nabi meyerahkan sepenuhnya kepada "ulama" Yahudi terkait hukuman apa yang pantas diberlakukan kepada pezina Yahudi sesuai dengan sanksi

${ }^{12}$ Sumber asli piagam madinah terdapat dalam Ibnu Hisyam, Sirah al-Nabawiyah, tahqiq Mustafa alSaqa, Ibrahim al-Abyari dan Abd al-Hafiz Syalabi, (t.tp.: t.tp., t.th.), 501-502.

${ }^{13}$ Dalam konteks modern, piagam madinah diumpamakan sebagai konstitusi. Walaupun pencantuman istilah piagam Madinah menjadi konstitusi Madinah menjadi bias jika pemaknaan konstitusi berangkat dari asumsi konstitusi dalam bentuk negara modern. Hal ini sepeti diakui Mahfud MD, piagam madinah tidak bisa disebut dengan konstitusi Madinah. Berbeda halnya dengan pendapat Jimly Asshiddiqie mengidentikkan piagam madinah sebagai konstitusi masyarakat madinah pada saat itu. Perbedaan cara pandang di atas dapat dilihat dari asumsi yang dibangun dalam melabelkan istilah konstitusi Madinah. 
yang ada dalam kitab Taurat. Dalam riwayat Ibnu Hisyam disebutkan bahwa "ulama" Yahudi tersebut menyerahkan sepenuhnya kepada Nabi hukuman yang akan dikenakan kepada pezina Yahudi. ${ }^{14}$

Kasus serupa juga dilakukan Yahudi warga negara Madinah berasal dari suku berbeda, yaitu bani Nadhir, bani Quraizah, ${ }^{15}$ dan suku Ghamidiyah. Berdasarkan riwayat al-Syaukani, sanksi yang diberikan Nabi kepada wanita Ghamidiyah adalah hukum rajam. ${ }^{16}$ Demikian pula penjatuhan hukumm rajam kepada Maiz bin Malik, Juhainah. ${ }^{17}$ Tradisi rajam bukanlah tradisi tradisi hukum yang bersifat orisinil dari ajaran al-Qur'an. Akan tetapi sumber hukum rajam adalah berasal dari tradisi Arab Jahiliyah. Harus diakui, terdapat hadis-hadis Nabi yang berbicara tentang hukum rajam, bukanlah dimaksudkan sebagai hukuman yang berasal dari tradisi hukum Islam. Hadis-hadis Nabi khususnya tentang rajam bersifat historis, bahkan telah dipraktekkan pada masa pra Islam cenderung kejam dan merendahkan kaum wanita. Hal ini diakui oleh Jimly, dalam pandangan agama Samawi, tradisi rajam, tradisi qishash berasal dari hukum Yahudi dan dipraktekkan oleh bangsa Mesir kuno, Hammurabi, walaupun dari segi orisinilitasnya masih diperselisihkan. ${ }^{18}$ Keraguan ini ditunjukkan Jimly dengan mengutip isi teks Kitab Johanes $8: 4$ :

"Master, this woman hatch been taken adultery, in the very act. Nowin the law Moses Commanded us to stone such; what then sayest thou of her?"19

Kebijakan Nabi dalam memutuskan perkara pezina Yahudi menunjukkan bekerjanya konsep pluralisme hukum dalam praktek masyarakat Madinah. Sejauh ini tidak ditemukan riwayat yang terindikasi adanya pemaksaan keberlakuan satu sistem hukum, yaitu hukum Islam. Dalam konteks ini, Nabi memahami adanya keragaman suku dan tradisi hukum yang berlaku pada masa Arab Jahiliyah. Untuk itulah, beberapa tradisi hukum yang berasal dari tradisi Arab Jahiliyah seperti tradisi hukum qishash dalam kasus tertentu masih diberlakukan. ${ }^{20}$ Tradisi hukum adat Arab Jahiliyah ini kemudian dimodifikasi menjadi lebih "rinagn", yang selanjutnya diadopsi oleh Islam melalui teologi 'uruf.

${ }^{14}$ Ibnu Hisyam, Sirah al-Nabawiyah..., Juz I, 564-565.

15 Jawwad Ali, al-Mufashshal fi Tarikh al-'Arab Qabl al-Islam, Juz VI, Cet. II, (Baghdad: Jami'ah Baghdad, 1993), 534-535; Ali, Hubungan al-Qur'an dan Hadis: Kajian Metodologis terhadap Hukuman Rajam, (Disertasi Pascasarjana UIN Ar-Rairy Banda Aceh, 2014), 238-240.

${ }^{16}$ Muhammad bin 'Ali bin Muhammad al-Syawkaniy, Nayl al-Awtar, Juz VII, (Beirut: Dar al-Jayl, t.th.), 116. Shahih Muslim, Juz XI, 199-203.

${ }^{17}$ Al-Nawawi, Shahih Muslim bi Syahr al-Nawawi, Juz XI, (Kairo: Mathba'ah al-Mishriyyah, 1929), 204-205.

${ }^{18}$ Jimly Asshiddiqie, Pembaharuan Hukum Pidana Indonesia, Edisi II, (Bandung: Angkasa, 1996), 59-60.

${ }^{19}$ Robert Robert, The Social Laws of the Qoran, Considerad and Compared with Those of the Hebrew and Other Ancient Codes, (New Delhi: Kitab Bhavan, 1997), 38-39; Jimly Asshiddiqie, Pembaharuan Hukum Pidana Indonesia..., 60-61.

${ }^{20}$ Ali Sodikin, Hukum Qishash: Dari Tradisi Arab Menuju Hukum Islam, (Yogyakarta: Tiara Wacana, 2010), 157. 


\section{Pluralisme Hukum: Instrumen Penguatan Masyarakat Madani}

Hubungan struktur sosial dengan hukum sangat relevan untuk didiskusikan dalam konteks penguatan masyarakat madani. Struktur sosial dalam suatu negara-bangsa belum tentu sama dengan struktur sosial yang dianut oleh negara lain. Setiap warga negara atau masyarakat memiliki identitas berbeda sebagai satu unsur subjektif yang dapat dilihat dalam hubungan dialektis. Perwujudan dari hubungan dialektis inimelahirkan paradigma bahwa identitas ini tidak muncul dengan sendirinya, melainkan dibentuk oleh proses sosial dan ditentukan oleh struktur sosial. Cara pandang ini adalah bentuk penafian dari adanya identitas kolektif yang banyak dianut oleh pengikut mazhab Durkheim. ${ }^{21}$

Sebaliknya identitas masyarakat dibentuk oleh struktur sosial memberi dampak pada sistem hukum yang dianut oleh masyarakat setempat. Sebagai contoh, identitas warga negara Indonesia berbeda dengan identitas warga negara Eropa. Indonesia sebagai bangsa majemuk memiliki beragam identitas yang melekat pada diri setiap warganya. Identitas yang dimiliki masyarakat Aceh berbedaa dengan identitas masyarakat Maluku, Sulawesi, Jawa dan identitas lainnya sebagai bagian dari keragaman suku, budaya dan agama.

Cara pandang demikian menurut adanya pengakuan berbagai identitas, turut mempengaruhi sistem nilai setiap individu masyarakat. Dalam konteks inilah, pemberlakuan sistem hukum yang bersifat sentralistik menjadi tidak relevan dan bahkan dapat dipastikan "gagal" mewujudkan rasa keadilan hukum dalam masyarakat plural. Fakta menunjukkan bahwa penggunaan hukum tunggal atau sistem hukum sipil, banyak dianut oleh negara-bangsa. Sistem hukum sipil tidak lain adalah hasil tranformasi kekuatan sosial, politik, ekonomi masyarakat Eropa mendorong lahirnya kelompok borjuis. Alasan demikianlah dapat dipahami bahwa sistem hukum civil law, sebagai representatif identitas masyarakat Eropa tidak dapat diterima begitu saja oleh negara-bangsa lain yang memiliki identitas tersendiri. Perbedaan struktur sosial, dinamika politik, turut mewarnai perbedaan dalam menentukan sistem hukum. Tipologi identitas yang dimiliki oleh masing-masing masyarakat atau warga negara menjadi mustahil jika diseragamkan atas dasar kepastian mendapat pengawalan dari negara. ${ }^{22}$ Konsep inilah yang mengilhami lahirnya kekuatan sistem hukum negara bergandengan dengan sistem hukum modern yang menganut azas rule of law.

Dominasinya sistem hukum modern dengan doktrin rule of law; supremacy of law, equality before the law, independent judiciary mendapat tanggap serius oleh Suteki. Ia membedakan bentuk dan substansi hukum modern. Secara bentuk, hukum modern bersifat publik, positif, otonom, dan berlaku umum. Sedangkan secara substansi memiliki azas dan doktrin. Penggunaan dari aspek bentuk sistem hukum modern masih dapat dikatakan relevan untuk diadopsi oleh negara lain. Akan tetapi dari segi substansinya, justru menimbulkan masalah lain mengingat adanya perbedaan doktrin rule of law dengan sistem nilai yang mengikat warganya pada suatu bangsa. ${ }^{23}$

\footnotetext{
${ }^{21}$ Peter L. Berger dan Thomas Luckmann, Tafsir Sosial Atas Kenyataan: Risalah Tentang Sosiologi Pengetahuan, terj. Hasan Hasari, Cet. x, (Jakarta: LP3ES, 2013), 235-237.

${ }^{22}$ Brian Z. Tamanaha, "Socio-Legal Positivism And A General Jurisprudence", Oxford Journal of Legal Studies, Vol. 21, No. 1, 2001, 17-18. (1-32).

${ }^{23}$ Suteki, Desain Hukum di Ruang Sosial, (Yogyakarta, Thafa Media, 2013), 181-186.
} 
Menyikapi sistem nilai yang terdapat dalam masyarakat plural agar selalu eksis keberlakuannya selalu mengacu pada landasan yuridis, filosofis, normatif dan sosiologi. ${ }^{24}$ Di era globalisasi, mengkaji persoalan hukum mengalami kemajuan, dengan tujuan agar hukum dapat berinteraksi dengan dunia global seperti hukum internasional, transnasional. Dalam konteks ini, pendekatan baru dapat diproyeksikan untuk merespon realitas masyarakat plural, adalah pendekatan sosio legal. ${ }^{25}$ David N. Schift berpendapat bahwa pendekatan sosio legal adalah salah satu pendekatan untuk menganalisis hukum dengan menghubungkan situasi sosial di tempat hukum itu diberlakukan. Hukum tidak hanya dipandang pada sisi normatifnya saja, melainkan juga mempertimbangkan sisi sosiologisnya dengan multi pendekatan. ${ }^{26}$

Mencermati pendekatan landasan dalam memahami hukum, muncul ketidakpuasan dari Werner Menski, jika memahami hukum hanya berkutat pada pendekatan-pendekatan di atas yang disebutnya dengan pendekatan klasik. Ia menawarkan pendekatan baru yang disebut dengan legal pluralism approach. Pendekatan legal pluralism atau pluralisme hukum mencoba mendialogkan hubungan antara negara yang menganut positive law dengan sistem nilai dalam masyarakat melalui pendekatan sosio-legal dan sistem natural law memuat ajaran moral, etika/religion. ${ }^{27}$

Saat ini pendekatan pluralisme hukum semakin banyak digeluti oleh para ahli yang concern mengikuti perkembangan teori hukum, terutama di Indonesia sebagai masyarakat plural. ${ }^{28}$ Cara pandang pluralisme hukum berbeda dengan cara pandang legal centralism yang menjadikan masyarakat sebagai objek hukum. Masyarakat diposisikan sebagai subjek pasif yang siap menerima aturan hukum yang dirumuskan oleh penguasa dalam bentuk regulasi. Sementara dalam konsep pluralisme hukum, penguatan masyarakat sipil menjaadi skala prioritas untuk berpartisipasi dalam membentuk sistem hukum yang plural.

Disini masyarakat dipandang sebagai subjek hukum yang memiliki hak dan kewajiban dalam menentukan sikap dalam berhukum. Batas-batas primordial tidak lagi dijadikan alasan sebagai ancaman terhadap ideologi suatu bangsa seperti yang dikonsepsikan oleh penguasa yang menganut sistem hukum sipil. Justru sebaliknya, keragaman hukum memperkuat ideologi suatu bangsa, karena konsepsi pluralisme hukum bukan melahirkan hukum baru, tetapi lebih menghidupkan kembali sistem hukum yang ada dalam setiap masyarakat majemuk.

Cara pandang dalam memahami keragaman sistem hukum seperti dikemukakan di atas merupakan ciri-ciri konsep masyarakat madani yang menganut sikap keterbukaan,

${ }^{24}$ Jimly Asshiddiqie, Pembaharuan Hukum Pidana Indonesia..., 11-13.

${ }^{25}$ Sulistiyowati Irianto, "Memperkenalkan Studi Sosiolegal dan Implikasi Metodologisnya" dalam Sulistiyowati Irianto dan Shidarta (ed.), Metode Penelitian Hukum: Konstelasi dan Refleksi, (Jakarta: Obor, 2009), 173-177.

${ }^{26}$ David N. Schiff, "Socio-Legal Theory: Social Structure and Law", Journal The Modern Law Review, Vol. 39, No. 3, May, 1976, 287-288. (287-310).

${ }^{27}$ Werner Menski, Comparative Law in a Global Contex: The Legal System of Asia and Afrika..., 187.

${ }^{28}$ Dalam konteks Indonesia, kajian khusus yang mencermati perkembangan hukum Indonesia dengan pendekatan pluralisme hukum dilakukan oleh Ratno Lukito, Legal Pluralism in Indonesia: Bridging the Unbridgeable, (New York: Routledge, 2013). Secara spesifik kajian pluralisme hukum juga dilakukan oleh Arskal Salim, Contemporary Islamic Law in Indonesia: Sharia and Legal Pluralism, (England: Edinburgh University Press, 2015), dan sejumlah tulisan lainnya juga membahas tentang pluralisme dalam bentuk artikel atau antologi pemikiran hukum. 
menegakkan kembali hak masyarakat, tatanan masyarakat mandiri dan demokratis, didukung oleh institusi-institusi negara dalam membangun negara dengan semangat toleransi dalam kemajemukan, kebebasan di ruang publik sehingga terwujudnya kesejahteraan dan keadilan sosial. ${ }^{29}$

Upaya mewujudkan masyarakat ideal seperti diinginkan dalam konsep masyarakat madani, diperlukan berbagai instrumen pendukung dalam rangka mewujudkan harmonisasi sistem hukum yang dipraktekkan oleh masyarakat majemuk. Dengan kata lain, ideologi pluralisme hukum dianggap relevan dalam upaya mengurangi dominasi hukum negara (sentralistik) sekaligus mengakui keberadaan sistem hukum yang hidup dalam masyarakat majemuk. Jika dipantulkan dengan keadaan negara Indonesia yang majemuk, pluralisme hukum justru sejalan dengan prinsip konstitusi atau kebhinekaan.

Kelanjutan dari pendekatan pluralisme hukum, secara teknis, perubahan sejumah regulasi yang memuat aturan hukum bersifat sentralistik perlu ditinjau kembali sejalan dengan prinsip pluralisme hukum. Meskipun demikian tidak semua regulasi yang sudah ada dapat dikatakan tidak sesuai dengan prinsip pluralisme. Akan tetapi diperlukan upaya untuk mengidentifikasi kembali sejumlah regulasi yang ada dan yang akan dirumuskan oleh penguasa atau negara, dipastikan mengakomodir keragaman sistem hukum yang ada dalam masyarakat. Di sisi lain negara juga mengakui atau memberi kebebasan kepada daerah tertentu melaksanakan hukum sesuai dengan identitas budaya masyarakat setempat. Hal ini telah dibuktikan oleh negara yang telah memberikan kewenangan melaksanakan hukum Islam (hukum agama), hukum adat dan hukum nasional (hukum negara) secara resmi berjalan di provinsi Aceh. Pelaksanaan hukum Islam (agama), dan hukum adat di daerah tertentu adalah bagian dari keanekaragaman sistem hukum yang memperoleh legitimasi dalam konstitusi Indonesia, dan bukan sebaliknya dipahami sebagai ancaman terhadap ideologi bangsa.

\section{Kesimpulan}

Dominannya hukum positif sebagai karakteristik hukum diyakini "gagal" mewujudkan rasa keadilan hukum masyarakat. Ideologi hukum negara mengedepankan asas keragaman hukum menggiring praktek hukum pada aspek tunggal. Akibatnya terjadi kemandegan perkembangan dan pembangunan hukum.respon terhadap keberpihakan negara pada sistem hukum sipil (civil law) yang berasal dari sistem hukum Eropa tidak relevan lagi untuk dipertahankan, apalagi diterapkan pada sistem hukum yang memiliki akar sosial budaya masyarakat berbeda. Upaya ke arah merevitalisasi sistem hukum yang hidup di masyarakat agar tetap berdampingan dengan sistem hukum negara membutuhkan sekap menghargai kemajemukan, demokrasi, perlindungan hak-hak minoritas malampaui batas-batas primordial. Konsep civil society atau masyarakat madani adalah solusi alternatif dalam usaha mengakomodir prinsip menghargai dalam perbedaan.

Civil society atau masyarakat madani tidak akan dapat tumbuh dan bertahan bila tidak didukung oleh kultur dan struktur sosial politik demokratis. Struktur sosial

${ }^{29}$ Mahfud MD, Aktualisasi Hukum Islam di dalam Masyarakat yang Plural, Kumpulan Makalah sebagai Bahan Kuliah pada Program Doktor Konsentrasi Ilmu Hukum dan Pranata Sosial Islam UIN Sunan Kalijaga Yogyakarta, 2016, 100-101. 
demokratis membutuhkan kekuatan civil seperti ormas, NGO, organisasi profesi memainkan peran maksimal untuk mencegah dominasi negara supaya tidak menjauhkan jarak hubungan sosial masyarakat. Keragaman identitas masyarakat bukanlah ditempuh dengan cara keseragaman hukum. Hal ini terbukti, negara belum berhasil melakukannya, bahkan dapat dipastikan setiap komunitas masyarakat menginginkan diberlakukannya kembali sistem hukum yang melekat pada masing-masing masyarakat.

Kenyataan demikian diperlukan pendekatan pluralisme hukum sebagai bagian upaya mendukung mewujudkan prinsip-prinsip masyarakat madani atau civil society. Pluralisme hukum menjadi instrumen pembangun hukum masyarakat majemuk yang memiliki keragaman budaya, identitas, sistem nilai tanpa mengenal batas teritorial atau primordial. Pendekatan pluralisme memaksimalkan kreativitas masyarakat secara individu dan kelompok sebagai subjek hukum untuk mewujudkan pembangunan dan penegakkan hukum, sekaligus mengharmonisasikan hukum-hukum yang hidup dalam masyarakat,; hukum agama, hukum adat, dan hukum negara agar dapat berjalan berdampingan sesuai dengan ideologi negara bangsa di era globalisasi. Kekhawatiran terhadap pluralisme hukum sebagai ancaman terhadap ideologi negara bangsa mulai memudar. Sebaliknya, pendekatan pluralisme hukum justru menguatkan kembali potensi yang dimiliki masyarakat, struktur sosial, identitas, dan kepercayaan kepada negara adalah cerminan dari karakteristik masyarakat berperadaban.

\section{Bibliography}

Ali, Hubungan al-Qur'an dan Hadis: Kajian Metodologis terhadap Hukuman Rajam, Disertasi Pascasarjana UIN Ar-Rairy Banda Aceh, 2014.

Ali, Jawwad. al-Mufashshal fi Tarikh al-'Arab Qabl al-Islam, Juz VI, Cet. II, Baghdad: Jami'ah Baghdad, 1993.

Al-Nawawi, Shahih Muslim bi Syahr al-Nawawi, Juz XI, Kairo: Mathba'ah al-Mishriyyah, 1929.

Asshiddiqie, Jimly. Pembaharuan Hukum Pidana Indonesia, Edisi II, Bandung: Angkasa, 1996.

Asy-Syawkaniy, Muhammad bin 'Ali bin Muhammad. Nayl al-Awtar, Juz VII, Beirut: Dar al-Jayl, t.th.

Azra, Azyumardi dkk., Mencari Akar Kultural Civil Society di Indonesia, Ciputa Jakarta: .INCIS, 2003.

Benda-Beckmann, Keebet. The Context of Law, xii th internasional Congress of the Commission on Folk Law and Legal Pluralism,: Legal Pluralism and Unofficial Law in Social, Economic and Political Development, Chiang Mai, April, 2002.

Culla, Adi Suryadi. Masyarakat Madani: Pemikiran, Teori dan Relevansinya dengan CitaCita Reformasi, Jakarta: Raja Grafindo Persada, 1999.

Faisal, Pluralisme Hukum di Indonesia: Kekuatan, Kelemahan, Peluang dan Ancaman, Yogyakarta: Maghza, 2013.

Hamim, Thoha. "Islam dan Masyarakat Madani", dalam Sudarno Shobron dan Mutohharun Jinan (ed.), Islam, Masyarakat Madani, dan Demokrasi, Yogyakarta: Muhammadiyah University Press, 1999. 
Hisyam, Ibnu. Sirah al-Nabawiyah, tahqiq Mustafa al-Saqa, Ibrahim al-Abyari dan Abd alHafiz Syalabi, t.tp.: t.p., t.th.

Irianto, Sulistiyowati. "Memperkenalkan Studi Sosiolegal dan Implikasi Metodologisnya" dalam Sulistiyowati Irianto dan Shidarta (ed.), Metode Penelitian Hukum: Konstelasi dan Refleksi, Jakarta: Obor, 2009.

Luckmann, Peter L. Berger dan Thomas. Tafsir Sosial Atas Kenyataan: Risalah Tentang Sosiologi Pengetahuan, terj. Hasan Hasari, Cet. x, Jakarta: LP3ES, 2013.

Lukito, Ratno. Legal Pluralisme in Indonesia: Bridging the Unbridgeable, New York: Routledge, 2013.

MD, Mahfud. Aktualisasi Hukum Islam di dalam Masyarakat yang Plural, Kumpulan Makalah sebagai Bahan Kuliah pada Program Doktor Konsentrasi Ilmu Hukum dan Pranata Sosial Islam UIN Sunan Kalijaga Yogyakarta, 2016.

Menski, Werner. Comparative Law in a Global Contex: The Legal System of Asia and Afrika, Cambridge University Press, 2006.

Nurjaya, I Nyoman. Perkembangan Pemikiran Konsep Pluralisme Hukum, dalam http://www.huma.co.id. (1-17).

Robert, Robert. The Social Laws of the Qoran,Considerad and Compared with Those of the Hebrew and Other Ancient Codes, New Delhi: Kitab Bhavan, 1997.

Salim, Arskal. Contemporary Islamic Law in Indonesia: Sharia and Legal Pluralism, England: Edinburgh University Press, 2015.

Schiff, David N. "Socio-Legal Theory: Social Structure and Law", Journal The Modern Law Review, Vol. 39, No. 3, May, 1976, (287-310).

Sodikin, Ali. Hukum Qishash: Dari Tradisi Arab Menuju Hukum Islam, Yogyakarta: Tiara Wacana, 2010.

Suteki, Desain Hukum di Ruang Sosial, Yogyakarta, Thafa Media, 2013.

Tamanaha, Brian Z. "Socio-Legal Positivism And A General Jurisprudence", Oxford Journal of Legal Studies, Vol. 21, No. 1, 2001.

Tim Penyusun Kamus Pusat Bahasa, Kamus Besar Bahasa Indonesia, Jakarta: Depdikbud, 1999.

Ubaidillah, A. dkk., Pendidikan Kewarganegaraan: Demokrasi, HAM dan masyarakat Madani, Jakarta: IAIN Jakarta Press, 2000.

Usman, Sunyoto. Esai-Esai Sosiologi Perubahan Sosial, Yogyakarta: Pustaka Pelajar, 2015

Wignjosoebroto, Soetandyo. Pergeseran Paradigma dalam Kajian-Kajian Sosial dan Hukum, Malang: Setara Press, 2013. 